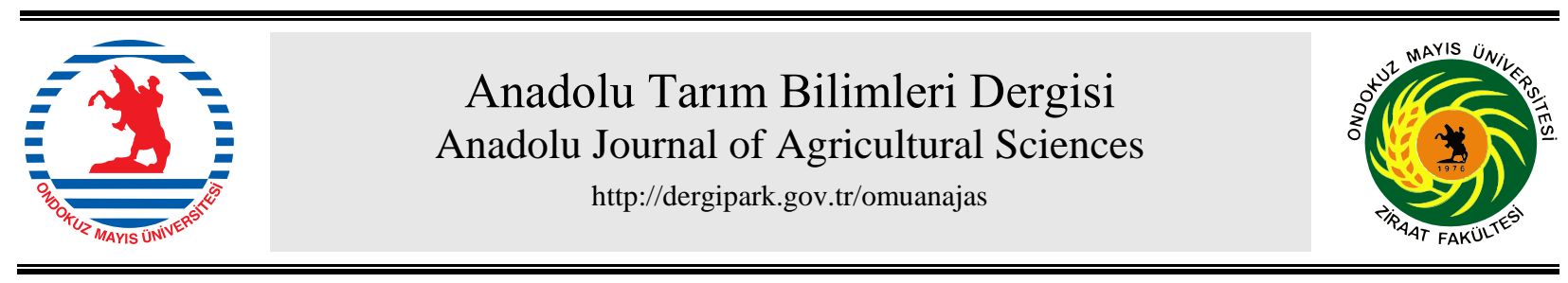

\title{
Araştırma/Research
}

Anadolu Tarım Bilim. Derg./Anadolu J Agr Sci, 34 (2019)

ISSN: $1308-8750$ (Print) 1308-8769 (Online) doi: $10.7161 /$ omuanajas.482710

\section{Misır (Zea mays L.) bitkisinin üşüme stresine toleransı sırasında yaprak büyüme bölgelerinde mikroRNA aracılıklı redoks regülasyonunun incelenmesi}

\author{
Fatma Aydınoğlu*, Burak Akgül \\ Gebze Teknik Üniversitesi, Moleküler Biyoloji ve Genetik Bölümü, Gebze / Kocaeli \\ *Sorumlu yazar/corresponding author: faydinoglu@gtu.edu.tr
}

Geliş/Received 14/11/2018～Kabul/Accepted 22/03/2019

\begin{abstract}
ÖZET
Ilıman iklim tahıllarından olan mısır (Zea mays L.) bitkisi, üşüme stresine oldukça duyarlıdır ve optimum büyüme ve yüksek verim için nispeten yüksek sıcaklığa ihtiyaç duyar. Üşüme stresi, büyüme işlevlerini sekteye uğratmakla birlikte hücrenin redoks homeostazisini bozarak oksidatif strese yol açar. Bu sırada açığa çıkan reaktif oksijen türleri (ROS)'in ise düşük miktarlarda büyümeyi teşvik ettikleri de bilinmektedir. Buradan yola çıkarak, bu çalışmada, mısır fidelerinin üşüme stresine karşı yaprak büyüme cevabının oluşumunda sinyal role sahip reaktif oksijen türlerinin microRNA (miRNA) genleri ile olası regülasyonunun araştırılması amaçlanmıştır. Bu doğrultuda, ADA 313 adlı mısır hibridi fidelerine üşüme stresi uygulanarak ROS üretimi tetiklenmiştir. Redoks regülasyonunda başlıca rol oynayan antioksidan genleri ve onları hedef alan microRNA'lar in silico analizlerle belirlenerek, aralarındaki ilişki transkripsiyonel ve enzimatik seviyede gösterilmiştir. Sonuç olarak, yaprak uzama oranı stres koşullarında kontrole göre \%19 azalmıştır. SOD $1 a$ genini hedef aldığı tahmin edilen miR528'in stres ve meristem, miR397 ve tahmini hedefi Lakkaz'1n olgunluk spesifik olduğu saptanmıştır. Katalaz (CAT), süperoksit dismutaz (SOD), glutatyon redüktaz (GR), peroksidaz (POX) ve askorbat peroksidaz (APX) antioksidan enzimlerinin aktivitelerinin büyüme bölgeleri arasında farklılık gösterdiği görülmüştür. $\mathrm{Bu}$ çalışma ile ilk defa, mısır bitkisinin üşüme stresine tolerans1 sırasında yaprak büyüme cevabında oksidatif sinyalizasyonun miRNA genleriyle regülasyonu gösterilmiştir.
\end{abstract}

Investigation of microRNA-mediated redox regulation in leaf growth regions during chiling stress tolerance of maize (Zea mays L.)

\begin{abstract}
Corn (Zea mays L.) is one of the temperate climate crops, very sensitive to chilling stress and needs relatively high temperature for optimum growth and high yield. Chilling stress disrupts growth processes coupled with disruption of redox homeostasis of the cell, leading to oxidative stress. It is also known that the low amount of reactive oxygen species (ROS) released during this period promote growth. From that view, the aim of this study was to investigate the possible microRNA (miRNA) mediated regulation of ROS playing signalling role in leaf growth response against the chilling stress of maize seedlings. In this respect, ROS production was triggered by applying low night temperature stress to maize hybrid seedlings named ADA313. The antioxidant genes that play a major role in the redox regulation and the microRNAs targeting them were determined by in silico analysis and the relationship between them was validated at the transcriptional and enzymatic level. As a result, the elongation rate of the fourth leaf was reduced by $19 \%$ by chilling stress compared to control. miR528, which was predicted to target SOD 1a gene was found meristem and stress specific. The expression of miR397, which was predicted to target Laccase, was detected at maturity. Enzymatic activities of catalase (CAT), superoxide dismutase (SOD), glutathione reductase (GR), peroxidase (POX) and ascorbate peroxidase (APX) were found to differ between the growth regions. In this study, the miRNA-mediated regulation of the oxidative signaling pathway was shown for the first time in the leaf growth zones of maize response to chilling stress.
\end{abstract}

Anahtar Sözcükler: miRNA ROS Oksidatif sinyalizasyon Yaprak büyümesi Misir
Keywords: Leaf growth miRNA Oxidative signaling ROS Zea mays 


\section{Giriş}

Misır, anavatanı Amerika olan ve dünyada buğday ve pirinçten sonra en fazla tarımı yapılan ılıman iklim tahıllarındandır. İnsan besini, hayvan yemi, sanayi hammaddesi ve son y1llarda özellikle biyodizel olarak kullanılması ile pek çok ülkenin tarımsal ürün deseninde kolayca yerini bulabilmiştir. Mısır yetişmesi için yüksek sıcaklık ve bol suya ihtiyaç duymasını nedeniyle düşük sicaklıklar ve kuraklık gibi abiyotik streslere ve bu streslerin yol açtığ ikincil stres olan oksidatif strese çok duyarlıdır. Bu stresler karşısında mısır büyümesi önemli derecede azalır. Yazın meydana gelen kuraklıktan sakınmak için mısır ekimi erken bahar aylarında yapılsa da erken dikim, tohum çimlenmesi ve fide büyümesi sırasında karşılaşılan üşüme stresi riskini artırmaktadır (Rymen ve ark., 2007). Bitkiler streslere karşı tolerans mekanizması geliştirerek büyümelerini yeniden düzenler ve böylece hayatta kalırlar (Wang ve ark., 2003). Stres tolerans1, çoklu genlerle kontrol edildiğinden günümüzde abiyotik streslere toleranslı mısır çeşidi geliştirilememiştir. Bu bağlamda, çeşitli streslere dirençli, büyüme ve verim potansiyeli yüksek bitkilerin geliştirilmesi için bu mekanizmaların aydınlatılması elzemdir.

Bitkilerde büyüme, pek çok genin rol aldığı hücre bölünmesi ve hücre genişlemesi işlevleri sonucu geri dönüşümsüz olarak gerçekleşen kütle artışı ile sağlanır (Beemster ve ark., 2003). Hücreler bölündükten sonra hücre genişlemesi ve hücre farklılaşması işlevleri ile olgun hale gelir. Mısır yaprağında, bu işlevler, tabandan itibaren meristem, uzama ve olgunluk olarak adlandırılan büyüme bölgelerinde zamana ve konuma bağlı olarak gerçekleșir (Inze ve ark., 2006). Ceșitli streslere maruz kalan bitkide, bu işlevlerin sekteye uğraması sonucu büyüme inhibisyonu gerçekleşir. Stres şiddeti ve süresine bağlı olarak, bitkide biyokütle azalış1, verim düşüklüğü ve hatta ölümler meydana gelir (Chinnusamy ve ark., 2007). Özellikle yaprak büyümesinin durması sonucu yaprak büyüklüğü etkilenerek fotosentez etkinliğinin önemli derecede düşmesi ve dolaysıyla biyokütle birikiminde azalış meydana gelir.

Hücre bölünmesi, diğer ökaryotik organizmalarda olduğu gibi, sikline bağlı kinazlar (CDK'ler) ile bitki hücre döngüsü sonucu gerçekleşir. Farklı $\mathrm{CDK}$-siklin kompleksleri, sırasıyla hücre döngüsünün G1-S ve G2$\mathrm{M}$ geçiş noktalarında bir dizi substratı fosforile ederek DNA replikasyonu ve mitoz başlangıcını tetikler. Siklin alt birimlerinin proteolitik tahribatının ardından mitoz sonlanarak ana hücreden iki kardeş hücre meydana gelir (Boudolf ve ark., 2004). Hücre genişlemesi, yeni bölünen hücrelerin çeperlerinin ekspansinler ile gevşetilmesini gerektirir. Hücre farklılaşması ise çeşitli gelişimsel ve çevresel sinyallere bağlıdır. Görüldüğ̈̈ gibi, büyüme çoklu genlerle kontrol edilmekte ve bu genlerin ifadesi biyotik ve abiyotik streslerle yeniden düzenlenmektedir. Organ büyüklüğü, hücre sayısı ve hücre büyüklüğüne bağlı olduğundan, çeşitli streslere dayanıklı, büyüme potansiyeli yüksek bitkiler elde etmek büyüme işlevlerinde yer alan bu genlerin rollerinin tanımlanması ve regülasyon mekanizmalarının anlaşılması ile mümkün olacaktır.

Üşüme stresi, 0 ila $15^{\circ} \mathrm{C}$ sıcaklıklarda gerçekleşir ve hücre içinde buz kristalleri oluşmaması ile soğuk stresinden ayrılır. Düşük sıcaklıklar, diğer tüm stres faktörleri gibi bitkilerde reaktif oksijen türleri (ROS)'nin üretilmesine yol açarak bitkide oksidatif strese neden olur (Scandalios ve ark., 2005; Rymen ve ark., 2007). ROS'lar hücrede lipid ve proteinlere, nükleik asitlere saldırarak yeni hücre yapımına engel olarak büyümeyi sekteye uğratır (de Azevedo Neto ve ark., 2006). Buna ek olarak, son y1llarda meristematik işlevlerin hücrenin redox durumundan etkilendiğini gösteren çalışmalar da birikmektedir (Considine ve Foyer, 2014; Avramova ve ark., 2015; Tsukagoshi, 2016; Mabuchi ve ark., 2018). İnsan hücre hatlarında yapılan çalışmalar hücrenin redox durumunun hücre bölünmesini etkileyerek büyümeyi teşvik ettiğini göstermiştir (Menon ve Goswami, 2007). Hücrenin redoks durumu, metabolizma sonucu üretilen reaktif oksijen türleri (ROS) ve onları parçalayan antioksidan sistem arasındaki dengedir. Bitkilerde ise ROS'un büyümeyi negatif ya da pozitif yönde etkilediği, bölünme, farklılaşma ve hücre ölümünde rol oynadığına dair bulgular olmasına rağmen hücre döngüsünün redoks ile regülasyon yolağı hayvanlardaki kadar tanımlanamamıştır (Lee ve ark., 2016).

ROS'ların sebep olduğu hasarı en aza indirmek için aerob canlılar enzimatik ve enzimatik olmayan savunma mekanizmaları geliştirmişlerdir (Scandalios, 2005). Hücrelerin geliştirdiği enzimatik savunma mekanizmaları elemanları arasında, süperoksit dismutaz (SOD), askorbat peroksidaz (APX), katalaz (CAT), glutatyon peroksidaz (GPX) ve peroksiredoksin (PRX), glutatyon redüktaz (GR) gibi enzimler vardır (Choudhury ve ark., 2017). Enzimatik olmayan antioksidanlar ise karotenoids, ksantafil, phenolics, flavonoids, tocopherols, ascorbic acids ve indirgenmiş glutathione gibi metaboliteleri içerir.

Bitkiler, çeşitli streslere karşı kendilerini, transkripsiyon sonrası regülasyon mekanizmalarında yer aldığı genetik ve epigenetik düzenlemelerle homeostaziyi yeniden sağlayarak savunurlar. Son yıllarda, pekçok biyotik ve abiyotik streslerde, büyüme ve gelişim gibi pekçok hücresel işlevde rol oynadığ gösterilen microRNA (miRNA) arac1lıklı gen regülasyonu bu mekanizmalardan biridir (Tollenaar ve Lee, 2002; Palatnik ve ark., 2003; Jones-Rhoades ve ark., 2004; Sunkar ve ark., 2007; Song ve ark., 2011; Sun, 2011). miRNA'lar, mRNA degradasyonuna ve translasyonel inhibisyona neden olarak hücrede çeşitli biyolojik süreçlerin düzenlenmesini sağlayan küçük ( 22nt), endojen ve kodlanmayan RNA grubudur. miRNA'lar hedef mRNA'larına, RNA susturulmasinda rol alan enzim kompleksleri aracılığıyla spesifik olarak bağlanırlar (Bartel, 2004; Sunkar ve ark., 2006). miRNA'ların sayısı ve üretimi canlılarda az olmasına 
rağmen, çoğunlukla transkripsiyon faktörlerini hedeflediklerinden etkileri büyüktür (Sunkar ve Jagadeeswaran, 2012). Arabidopsis bitkisinde yapilan araştırmalar, miR398 geninin iki $\mathrm{Cu} / \mathrm{Zn}$ superoxide dismutases (CSD1 ve CSD2) genini hedef alarak ifadelerini negatif olarak düzenlediğini göstermiştir ( $\mathrm{Li}$ ve ark., 2017). Diğer bir çalışmada ise, miR408 genini aşırı ifade eden Arabidopsis mutantında, tuz, kuraklık, ağır metal gibi abiyotik stres sonucunda, yine CSD1 ve CSD2 ifadelerinin negatif düzenlenmesi ile ROS artış1 saptanmıştır (Ma ve ark., 2015). Yine, miR528 genininin pirinç bitkisinde oksidatif streste rol aldığ 1 gösterilmiştir (Liu ve ark., 2015).

ROS hücrede günlük metabolik olaylar sırasında sürekli üretilmekte ve degredasyona uğratılmaktadır. ROS'un eşik değerini aşması hücrede oksidatif strese neden olmakta ve oksidatif sinyal yolağını başlatarak bitkinin strese toleransını sağlamasına yardımcı olmaktadır. Ayrıca, ROS'un düşük miktarlarda büyümeyi teşvik ettiği bilinmektedir. ROS'un hücredeki degredasyonu genetik kontrol altındadır. Ancak, bu yolaklarda görevli pek çok gen hala bilinmemektedir. Tüm bunlardan yola çıkarak; bu çalışmanın amacı, mısır yaprağının büyüme bölgeleri arasında ROS'un degredasyonunda rol oynayan miRNA aracılıklı yolağın aydınlatılmasıdır. $\mathrm{Bu}$ amaç doğrultusunda; mısır fidelerine düşük gece sıcaklığı uygulanarak büyüme aksaklığı meydana getirilmiştir. Fideler sürekli büyüme (steady-state) aşamasında iken hasat edilerek, dördüncü yapraklarının büyüme bölgelerindeki antioksidan enzimlerinin aktiviteleri ölçülmüş ve bu enzimlerin gen ekspresyonunu düzenleyen miRNA'lar belirlenerek aralarındaki olası ilişki transkripsiyonel analizler ile doğrulanmaya çalışılmıştır. Böylece, bu çalışmada, mısır yaprağının büyüme sürecinde üşüme stresi ile ortaya çıkan ROS'un degredasyonunda rol oynayan redoks sisteminde miRNA genlerinin olası rolünün araştırılması hedeflenmiştir.

\section{Materyal ve Yöntem}

\subsection{Bitki materyali, büyütme koşulları ve morfolojik gözlemler}

Bitki materyali olarak Türkiye'de yetiştirilen ve Mısır Araştırma İstasyonu Müdürlüğü tarafindan 2011 yılında tescillenen ADA313 adlı misir hibriti (Zea mays L.) kullanılmıştır. Karşılaştırmalı analizler için optimum şartlarda yetiştirilen bir kontrol grubu ve üşüme stresine maruz birakılan bir stres grubu oluşturulmuştur. Yetiştirme şartları, her iki grup için fotoperiyot 16/8 saat aydınlık/karanlık, nispi nem \%70, 1şık yoğunluğu 18000 lux olarak uygulanırken, sicaklık kontrol grubu için $25^{\circ} \mathrm{C} / 20^{\circ} \mathrm{C}$ ve stres grubu için $25^{\circ} \mathrm{C} / 4^{\circ} \mathrm{C}$ (aydınlık/karanlık) olarak belirlenmiştir. Her iki grup için, mısır tohumları önce viyollere ekilerek iklim dolabında kontrol şartlarında çimlenmeye bırakılmıştır. Çimlenmenin ardından, koleoptilleri çıkan tohumlar viyollerden içerisinde torf bulunan 1,5 lt'lik saksılara ekilip, hemen iklim dolabına aktarılarak kontrol ve üşüme stresi şartlarında dördüncü yaprakları tamamen olgunlaşıncaya kadar yetiştirilmiştir.

Fidelerin dördüncü yapraklarının uzunluğu, ortaya çıktıkları andan, tamamen olgunlaşıncaya kadar günlük olarak ölçülmüştür. Yaprak uzunluğunun türevi alınarak yaprak uzama oranı (YUO) hesaplanmıştır. Gruplar arasındaki farkın önem derecesi Microsoft Excell programinda yer alan Student's T-testi'ne göre belirlenmiștir.

Çizelge 2.1. Çalışılan miRNA ve hedef genlerin primerleri

\begin{tabular}{|c|c|c|c|c|c|c|}
\hline $\begin{array}{l}\text { Gen İsmi / } \\
\text { Gen kodu }\end{array}$ & & $\begin{array}{l}\text { İleri/Geri Primerler } \\
\left(5^{\prime} \rightarrow 3^{\prime}\right)\end{array}$ & Uzunluk & $\begin{array}{l}\text { Tm } \\
\left({ }^{\circ} \mathbf{C}\right)\end{array}$ & $\begin{array}{l}\text { GC } \\
(\%)\end{array}$ & $\begin{array}{l}\text { Hetero dimer } \\
\text { (Delta G) } \\
\text { (kcal/mole) }\end{array}$ \\
\hline miR397a-5p / & ileri & CTCTGCAAAAGACACGTTCA & 20 & 61 & 45 & -8.65 \\
\hline MIMAT0014018 & Stem loop & $\begin{array}{l}\text { GTCGTATCCAGTGCAGGGTCCGAGGTATTCGC } \\
\text { ACTGGATACGAC CATCAA }\end{array}$ & 50 & 54 & 70 & \\
\hline L-ascorbate oxidase / & I Ileri & CACGTTCAAGCTGAAAGTGA & 18 & 61 & 45 & -3.61 \\
\hline Zm00001d042905 & Geri & CGGCGATGGAGAAGAAGA & 17 & 61 & 55.6 & \\
\hline Laccase-like (lac4) I & İleri & ACAACTGCTCTGCCAAAG & 18 & 60 & 53 & -3.14 \\
\hline Zm00001d042906 & Geri & TTGGCGACGGAGAAGAA & 17 & 60.5 & 65 & \\
\hline \multirow{2}{*}{$\begin{array}{l}\text { Superoxide } \\
\text { dismutase[Cu-Zn] / } \\
\text { GRMZM2G106928 }\end{array}$} & $\begin{array}{l}\text { İleri } \\
\text { Geri }\end{array}$ & $\begin{array}{l}\text { GCGCAGTCCTTCCTCCT } \\
\text { CGAAGTGGACCGAGTGGAAA }\end{array}$ & 17 & 63 & 65 & -6.59 \\
\hline & & & 18 & 63 & 55 & \\
\hline \multirow{4}{*}{$\begin{array}{l}\text { zma-miR528a-5p / } \\
\text { MIMAT0014028 }\end{array}$} & İleri & CTAGTGGAAGGGGCATGC AG & 20 & 60 & 58 & -8.65 \\
\hline & Stem loop & GTCGTATCCAGTGCAGGGTCCGAGGTATTCGC & & & & \\
\hline & & ACTGGATACGACCTCCTC & 50 & 54 & 70 & \\
\hline & $\begin{array}{l}\text { Evrensel } \\
\text { geri }\end{array}$ & GTG CAG GGT CC GAG GT & & & & \\
\hline
\end{tabular}




\subsection{Klorofil miktarl tayini}

Kontrol ve stres şartlarında yetiştirilen fidelerin dördüncü yapraklarının klorofil miktarları Lichtenthaler ve Buschmann (2001)'nın tanımladığı yönteme göre hesaplanmıştır. Buna göre, yaprakların 10-15 cm'si alınarak \%80'lik $5 \mathrm{ml}$ aseton solüsyonu içinde homojenize edilip, 2000 rpm'de 3 dk santrifüj edilmiştir. Süpernatant alınarak 1:1 (v/v) oranında yine aynı solüsyonla seyreltilerek 663, 646 ve 470 dalga boylarında spektrofotometre ile absorbans (A) değerleri ölçülmüştür.

\section{3. miRNA ve hedef genlerinin belirlenmesi ve primer tasarımı}

ROS'un bertaraf edilmesi yolağında rol oynayan miRNA ve hedef genlerinin transkripsiyonel analizleri için ilk olarak misır bitkisinin antioksidan enzimleri kodlayan genleri Avromova ve ark., (2015)'den elde edilmiştir. Aynı zamanda, literatürde diğer bitkiler üzerinde yapılan benzer çalışmalara bakılarak oksidatif streste rol oynayan miRNA'lar belirlenmiştir (ChavezHernandez ve ark., 2015). Antioksidan genlerine ait kodlama yapan diziler (CDS), misır genetik ve genomik veri bankasindan (https://www.maizegdb.org/), misir bitkisi miRNA genlerine ait diziler ise miRBASE veri bankasından (www.mirbase.org/) elde edilmiştir. miRNA ve olası hedef genleri, psRNATarget web servisi (http://plantgrn.noble.org/psRNATarget/) kullanılarak tahmin edilmiştir (Dai ve Zhao, 2018).

miRNA hedef genlerine ait qRT-PCR primerleri, SCiTools OligoAnalyzer 3.1 web servisi (http://www.idtdna.com/pages/tools) yardımıyla tasarlanmıştır ve erime sicaklığı (Tm)'si $58-61^{\circ} \mathrm{C}$, $50^{\circ} \mathrm{C}$ 'de hairpin formasyonu $\Delta \mathrm{G}>-3 \mathrm{kcal} / \mathrm{mol}, 50^{\circ} \mathrm{C}^{\prime} \mathrm{de}$ self ve cross dimer formasyonu $\Delta \mathrm{G}>-6 \mathrm{kcal} / \mathrm{mol}$ olacak şekilde kontrol edilmiştir. Primer özgünlüğü için BLASTn (https://www.ncbi.nlm.nih.gov/BLAST/) algoritması kullanılmıştır.

miRNA genleri için, stem-loop RT-PCR ve qRTPCR primerleri, Chen ve ark. (2005)'nın tanımladığ 1 şekilde tasarlanmıştır. Stem-loop RT primerler, her bir miRNA'ya spesifik olacak şekilde, evrensel bir stemloop'un 3' ucuna, her bir miRNA'nın 3' ucuna komplementar 6 nükleotidin eklenmesiyle elde edilir. Tasarlanan bu primerler miRNA cDNA sentezinde kullanılacaktır. qRT-PCR için, ileri primerler, miRNA sekansına özgü fakat 3' ucuna rastgele 6 nükleotid eklenerek tasarlandı ve geri primer ise, stem-loop dizesine komplementer olarak evrenseldir. Primer özgünlüğü ve sekonder yapı formasyonları yukarıdaki kriterlere göre kontrol edilmiştir. Transkripsiyonel analizlerde kullanılan tüm primerler Çizelge 2.1.'de sunulmuştur.

\section{4. miRNA ve tahmini hedef genlerinin transkripsiyonel analizleri}

Mısır fidelerinin dördüncü yaprakları, çıktıktan 48 saat sonra hasat edilerek, meristem, uzama ve olgunluk bölgelerine ait 1'er cm'lik doku örneklerinden toplam RNA ekstraksiyonu TRIzol metoduna göre yapılmıştır. İzole edilen RNA'ların miktarları ve saflığı NanoDrop ND-1000 UV-VIS spektrometre cihazı ile belirlenmiştir. miRNA'lar için cDNA sentezi, Varkonyi-Gasic vd., (2007)'in tanımladığı protokol adımları takip edilerek stem-loop primerler kullanılarak High-Capacity cDNA Reverse Transcription Kit'i (Thermo Fisher) ile yapılmıştır. Burada $2 \mu \mathrm{g}$ toplam RNA kullanılmıştır. Stem-loop RT, önce reverse transkriptaz ve ardından pulsed RT PCR işlemlerini içerir.

miRNA hedef genleri için cDNA sentezi, aynı kit ile $1 \mu \mathrm{g}$ RNA kullanılarak kitin içinde bulunan random primerler kullanilarak reverse transkriptaz enzimi ile sentezlenmiştir.

miRNA ve hedef genlerinin ifadesi Applied Biosystems StepOne ${ }^{\text {TM }}$ Real-Time-PCR sistemi ile Power SYBR $\AA$ Green PCR Master Mix (Thermo Fisher) kiti kullanılarak belirlenmiştir. Nisbi (relative) ekspresyon miktarı deltadelta $\mathrm{Ct}\left(2^{-\Delta \Delta \mathrm{Ct}}\right)$ metoduna göre belirlenmiştir. Analizler, 3 biyolojik ve 2 teknik tekrarlı olarak yapılmıştır. Veriler, $\beta$ _Tubilin ve EFla genleri kullanılarak normalize edilmiştir (Pfaffl, 2001).

\subsection{Enzimatik Analizler}

Mısır fidelerinin dördüncü yaprakları, çıktıktan 48 saat sonra hasat edilerek, tüm büyüme bölgelerini içeren yaprak tabanından itibaren $10 \mathrm{~cm}$ 'lik kısmı 1'er cm'lik doku örneklerine ayrılmıştır. Her bir doku örneğinden ayrı ayrı protein ekstraksiyonu Kayıhan ve ark. (2016)'na göre yapılmıştır. Doku örnekleri, hasatın hemen sonrasında, içinde üç adet kürecik (4 cm çaplı) bulunan eppendorf tüplerde sıvı azot ile fikse edilerek analizlere kadar $-80^{\circ} \mathrm{C}$ 'de muhafaza edilmiştir. Örnekler, 45 saniye süreyle 25 frekansta doku parçalayıcı ile homojenize edilmiştir. Örnekler, üzerlerine $50 \mathrm{mM} \mathrm{KH}_{2} \mathrm{PO}_{4}(\mathrm{pH}=7,8), 1 \mathrm{mM}$ EDTA, \%2 PVP içeren $1 \mathrm{ml}$ ekstraksiyon tamponu konulup iyice vortekslendikten sonra, 10.000 rpm'de 30 dakika boyunca $+4^{\circ} \mathrm{C}$ 'de santrifüj edilmiştir. Santrifüjlenen örneklerin süpernatant kısımları, yeni ependorflara alınıp $-20^{\circ} \mathrm{C}^{\prime}$ ye kaldırılmıştır. Total protein miktarı tayini Bradford (1979)'a göre yapılmıştır. Deneyde, 0.1 $\mathrm{mg} / \mathrm{ml}, 0.2 \mathrm{mg} / \mathrm{ml}, 0.4 \mathrm{mg} / \mathrm{ml}, 0.6 \mathrm{mg} / \mathrm{ml}, 0.8 \mathrm{mg} / \mathrm{ml}, 1$ $\mathrm{mg} / \mathrm{ml}$ konsantrasyonlu BSA standartları kullanılmıştır. Örneklerin protein miktarı, 10 dakika Bradford ayıracı ile inkübe edilen BSA standartlarının bilinen konsantrasyonuna karşı 595 nm'deki absorbans değerleri ile elde edilen standart eğriye göre hesaplanmıştır.

\subsection{Enzim aktivitesi ölçümü ve biyokimyasal analizler}

Katalaz enzim aktivitesi Chance ve Maehly (1995)'nin makalesinde önerilen metoda göre yapılmıştır. Reaksiyon, $50 \mathrm{mM}$ potasyum fosfat tamponu, $200 \mathrm{mM} \mathrm{H} \mathrm{O}_{2}, 50 \mu \mathrm{l}(4-11 \mu \mathrm{g} / \mathrm{ml})$ protein 
ekstraktı kullanılarak gerçekleştirilmiştir. Örneklerin 90 saniye boyunca $240 \mathrm{~nm}$ 'deki absorbans değerleri değişimi spektrofotometre (Shimadzu-1800) cihazında ölçülüp kaydedildi. Katalaz enzim aktivitesi, Aebi (1983)'e göre hesaplanmıştır.

Süperoksit dismutaz enzim aktivitesi Banowertz ve ark. (2004) makalesinde önerilen metoda göre yapılmıştır. Reaksiyon, $250 \mathrm{mM}$ potasyum fosfat tamponu ( $\mathrm{pH}=7.8), 100 \mathrm{mM}$ metionin, 5mM EDTA, $750 \mathrm{mM} \mathrm{NBT}, 20 \mu \mathrm{l}$ protein ekstrakt1, 0.002 gr riboflavin kullanılarak gerçekleştirildi. Örnekler, $10 \mathrm{dk}$ 1şık altında inkübe edildikten sonra $560 \mathrm{~nm}$ de absorbans değerleri kaydedilmiștir. Bir ünite enzim, 540 nm'deki kromojen üretiminden kaynaklanan absorbans farkını, deney koşulları altında bir dakikada \% 50 oranında inhibe etmek için gerekli enzim miktarıdır. SOD aktivitesi $\mathrm{SA}=$ mol UA $/ \mathrm{mg}$ protein olarak sunulmuştur.

Glutatyon redüktaz enzim aktivitesi Eker ve ark. (2006)'nin makalesinde önerilen metoda göre yapılmıştır. Reaksiyon, $50 \mathrm{mM}$ potasyum fosfat ve 0.1 mM EDTA, 0,5 mM GSSG, 0,12 mM NADPH, $50 \mu \mathrm{l}$ protein ekstraktı kullanılarak gerçekleştirilmiştir. Örneklerin, $340 \mathrm{~nm}$ de 3 dakika boyunca absorbans değişimleri ölçülmüştür. Glutayon redüktaz enziminin aktivitesi, Carlberg ve Mannervik (1975)'e göre hesaplandı. 1 ünite enzim, $1 \mu \mathrm{M}$ NADPH $/ \mathrm{min} / \mathrm{g} \mathrm{FW}$ oksidize etmek için gerekli enzim miktarı olarak sunulmuştur.

Peroksidaz enzim aktivitesi Quesada ve ark. (1992)'ın makalesinde önerilen metoda göre yapılmıştır. Reaksiyon, $50 \mathrm{mM}$ potasyum fosfat tamponu, $50 \mu \mathrm{l}$ protein ekstrakt1, $10 \mathrm{mM} \mathrm{H} 2 \mathrm{O} 2, \% 0.02$ dianizidin kullanılarak yapılmıștır. Örneklerin $1.5 \mathrm{dk}$ boyunca 460 nm'deki absorbans değişimleri ölçülmüştür. Peroksidaz enziminin aktivitesi, Quesada ve ark. (1992)'e göre hesapland1. 1 ünite enzim, $1 \mu \mathrm{M} \quad \mathrm{H}_{2} \mathrm{O}_{2}$ 'yi oksidize etmek için gerekli enzim miktarı olarak sunulmuştur.

Askorbat peroksidaz enzim aktivitesi Nakada ve Asada (1981)'nın makalesinde önerilen metoda göre yapılmıştır. Reksiyon, $50 \mathrm{mM}$ potasyum fosfat, 0.25 $\mathrm{mM}$ askorbik asit, $1 \mathrm{mM} \mathrm{H}_{2} \mathrm{O}_{2}$ ve $50 \mu \mathrm{l}$ protein kullanılarak yapılmıștır. Örneklerin 290 nm'de 3 dakika boyunca absorbans değişimleri ölçülmüsşür. Askorbat peroksidaz enziminin aktivitesi, Nakano ve Asada (1981))'e göre hesapland1. 1 ünite enzim $1 \mu \mathrm{M}$ askorbatı oksidize etmek için gerekli enzim miktarı olarak sunulmuştur.

Her bir doku örneğinde, Malondialdehit (MDA) ve Hidrojen Peroksit $\left(\mathrm{H}_{2} \mathrm{O}_{2}\right)$ miktarı, sirasıyla Heath ve Packer (1968) ve Sergiev vd (1997)'nin makalelerinde önerilen metotlara göre yapılmıștır. Buna göre, örnekler 25 frekans $/ 45$ saniyede doku parçalayıcısı ile homojenize edildikten sonra $1 \mathrm{ml} \quad \% \quad 0.1 \quad$ TCA (trikoloroasetikasit) ile muamele edilerek buza alınmıştır. Ardından, 10.000 rpm'de 15 dakika boyunca santrifüj edilen örneklerin süpernatantları temiz ependorflara alınmıştır.

MDA miktar tayini için, $250 \mu \mathrm{l}$ süpernatant, 100
$\mathrm{mM} 250 \mu \mathrm{l}$ Tris- $\mathrm{HCl}(\mathrm{pH}=7.6), 250 \mu \mathrm{l}$ TCA, TBA, HCl karışımı (\%15 TCA, 0.375 TBA, $250 \mathrm{mM} \mathrm{HCl})$ koyulup, $95{ }^{\circ} \mathrm{C}$ 'de 45 dakika sicak su banyosunda inkübe edilmiştir. 45 dakika sonunda örnekler buza koyulup soğumaları sağlandıktan sonra, örnekler, buzdan alınıp 10.000 rpm'de 5 dakika santrifüj edilmiştir. $200 \mu \mathrm{l}$ süpernatant alınıp $600 \mathrm{~nm}$ ve 532 nm'de absorbans değerleri ölçülmüştür.

$\mathrm{H}_{2} \mathrm{O}_{2}$ miktarı tayini için, $250 \mu \mathrm{l}$ süpernatant, $100 \mathrm{mM}$ $250 \mu \mathrm{l}$ Tris-HCl, $1 \mathrm{M} 500 \mu \mathrm{KI}$ (potasyum iyodür) ile muamele edilerek 90 dakika boyunca oda sıcaklığında karanlıkta inkübe edilmiştir. 90 dakika sonunda örneklerden $200 \mu \mathrm{l}$ alınıp 390 nm'deki absorbans değerleri ölçülmüştür.

\subsection{Istatistiksel Analizler}

Deneyler üç biyolojik ve iki teknik tekrarlı yapılmıştır. Sonuçlar ortalama olarak verilmiş ve hata çubukları standart hata olarak heasplanmıştır. Kontrol ve stres grupları arasındaki farkın önem derecesi Microsoft excel Student's T-test'i kullanılarak hesaplanmıştır. Gruplar arasındaki farkın önem derecesi (P) 0.05 'den küçük $(\mathrm{P}<0,05)$ olarak alınmıştır.

\section{Bulgular ve Tartışma}

\subsection{Morfolojik analizler ve klorofil tayini}

Bu çalışmada, mısır (Zea mays L.) bitkisinin üşüme stresine toleransı sırasında, yaprak büyüme işlevlerinin yeniden düzenlenmesinde hücrenin redoks homeostazisinin sağlanmasında mikroRNA (miRNA) genlerinin olas1 rollerinin araştırılması amaçlanmıştır. $\mathrm{Bu}$ amaç doğrultusunda, ADA313 adlı hibrid mısır fidelerine, çimlenmelerinin ardından model olarak kullanılan dördüncü yaprakları tamamen olgunlaşıncaya kadar üşüme stresi uygulanmıştır. Stresin fideler üzerinde meydana getirdiği etkiler, optimum şartlarda yetiştirilen fideler ile karşılaştırmalı analizler sonucunda ortaya konulmuştur. $\mathrm{Bu}$ bağlamda, mısır fidelerinin dördüncü yaprakları ortaya çıkışlarından tamamen olgunlaşıncaya kadar toprak seviyesinden yaprak ucuna doğru günlük olarak ölçülmüştür. Sonuç olarak, üşüme stresinin, fidelerin dördüncü yapraklarının uzunluğu (YU)'nda, kontrol grubuna göre istatistiksel olarak önemli derecede \%26 oranında azalışa neden olduğu saptanmıştır. Fidelerinin dördüncü yapraklarının uzama oranı (YUO)'nında ise üşüme stresine bağlı olarak \%19 oranında istatistiksel olarak önemli derecede azalış saptanmışır $\quad(\mathrm{P}<0,05) \quad$ (Çizelge 3.1.). Kontrol grubundaki fidelerin dördüncü yapraklarının dört gün boyunca sabit oranda büyüdüğü fakat büyüme oranının azalarak sekizinci günde durduğu, stres grubunda bulunan fidelerin dördüncü yapraklarının ise altı gün boyunca sabit büyümeye devam ettiği ve sonrasında büyümenin azalarak onuncu güne doğru durduğu gözlenmiştir. Böylece, uygulanan üşüme stresinin, yaprak büyümesini iki gün gecikmeye uğrattığı 
gözlenmiştir. Bu bağlamda, bu çalışmada, amaçlandığı gibi, bitkilere uygulanan stres şiddeti, zamanı ve süresinin bitkilerde fotosentez gibi önemli metabolik aktiviteleri sekteye uğratmadan büyüme geriliğinin meydana getirildiği gözlenmiştir (Rymen ve ark., 2007).
Nitekim, her iki grupta yetiştirilen fidelerin dördüncü yapraklarının klorofil miktarlarında fark saptanmaması bunu doğrulamaktadır (Çizelge 3.1). Böylece üşüme stresi sırasında üretilen ROS'ların büyümedeki rolleri ile ilişki doğrudan kurulabilecektir.

Çizelge 3.1. Kontrol ve üşüme stresi şartlarında yetiştirilen fidelerin üçüncü ve dördüncü yaprakların morfolojik parametreleri

\begin{tabular}{|c|c|c|c|c|}
\hline & & $\begin{array}{c}\text { Kontrol } \\
\text { Y4 }\end{array}$ & $\begin{array}{c}\text { Stres } \\
\text { Y4 }\end{array}$ & $\begin{array}{c}\text { Fark (\%) } \\
\text { Y4 }\end{array}$ \\
\hline Yaprak uzunluğu (YU) (mm) & & $719 \pm 26$ & $533 \pm 9$ & $26^{* *}$ \\
\hline Yaprak uzama oranı (YUO) $(\mathrm{mm} / \mathrm{sa})$ & & $3.5 \pm 0.2$ & $2.3 \pm 0.1$ & $19 * *$ \\
\hline Yaprak alanı (YA) $\left(\mathrm{mm}^{2}\right)$ & & $16871 \pm 1150$ & $10990 \pm 876$ & $35^{* *}$ \\
\hline & Klorofil a & $26 \pm 2$ & $29 \pm 4$ & -10 \\
\hline & Klorofil b & $8 \pm 1$ & $7 \pm 2$ & 2 \\
\hline & Karotenoid & $9 \pm 0$ & $9 \pm 1$ & - \\
\hline
\end{tabular}

** $(\mathrm{p}<0,01)$ student Ttest: iki kuyruklu dağılım; iki örnek eşit olmayan varyans. Y4: dördüncü yaprak.

\subsection{Redoks regülasyonunda olası role sahip miRNA ve tahmini hedef genlerinin ifade analizleri}

Redoks regülasyonunda olası role sahip miRNA'lar literatür çalışmalarıyla belirlenmiştir. Buna göre, miR397a-5p'nin Lakkaz'1, miR528a-5p'nin Süperoksit dismutaz (SOD-1A)'1, miR398'in Cu/Zn Süperoksit dismutaz'1, miR529'un Peroksidaz'1 ve miR408'in CSD'yi hedefleyerek oksidatif streste rol oynadığı, Zea mays, Arabidopsis tahliana, Brassica napus bitkilerinde gösterilmiştir (Çizelge 3.2). Bu miRNA'ların, mısır bitkisindeki homologlarının dizeleri miRBase veri bankasından elde edilmiştir ve hedef aldıkları genler psRNATarget web aracı kullanılarak in silico analizler ile tahmin edilmiştir. $\mathrm{Bu}$ tahmin aracı, bitki mamiRNA'ların ve hedef transkriptlerin arasında son derece yüksek baz eşleşmesi olması gerçeğine dayanır (Dai ve ark., 2018). Ayrıca, bu analiz, miRNA için tahmin edilen hedefin yapısal erişilebilirliğini de değerlendirir. Böylece, bitki miRNA hedef genleri yüksek doğrulukla tahmin edilebilmektedir.

Çizelge 3.2. İn siliko olarak bulunan miRNA ve hedef genleri

\begin{tabular}{|c|c|c|c|}
\hline miRNA & Hedef & Bitki & Referans \\
\hline miR397a-5p & LAC2; lakkaz & Zea mays & $\begin{array}{l}\text { Chavez-Hernandez ve ark., } 2015 \\
\text { Khraiwesh ve ark., } 2012 \\
\text { Zhang ve ark., } 2013\end{array}$ \\
\hline miR528a-5p & $\begin{array}{l}\text { SOD-1A; Süperoksit } \\
\text { dismutaz [Cu-Zn] }\end{array}$ & Zea mays & Chávez-Hernández ve ark., 2015 \\
\hline miR398 & $\begin{array}{l}\mathrm{Cu} / \mathrm{Zn} \text { Süperoksit } \\
\text { Dismutaz }\end{array}$ & $\begin{array}{l}\text { Arabidopsis } \\
\text { thaliana }\end{array}$ & $\begin{array}{l}\text { Sunkar ve ark., } 2006 \\
\text { Chinnusamy ve ark., } 2007 \\
\text { Zhu ve ark., } 2016 \\
\text { Jagadeeswaran ve ark., 2009, Chinnusamy } \\
\text { ve ark., 2007, Kumar ve ark, } 2015\end{array}$ \\
\hline $\begin{array}{l}\text { Mir529 } \\
\text { miR408 }\end{array}$ & $\begin{array}{l}\text { peroksidaz } \\
\text { CSD }\end{array}$ & $\begin{array}{l}\text { Brassica napus } \\
\text { Arabidopsis } \\
\text { thaliana }\end{array}$ & $\begin{array}{l}\text { Xie ve ark., } 2007 \\
\text { Kumar ve ark, } 2013\end{array}$ \\
\hline
\end{tabular}

Literatür ve in siliko analizler ile redoks regülasyonunda rol oynayabileceği belirlenen miRNA'lar ve tahnini hedef genlerinin aralarındaki olası ilişki, qRT-PCR analizleri ile gösterilmiştir. Bu bağlamda, fidelerin dördüncü yaprakları büyümenin sabit (steady-state) fazında hasat edilerek meristem (hücre bölünmesi), uzama (hücre genişlemesi) ve olgunluk (hücre farklılaşması) olan büyüme ve gelişim evrelerinden alınan birer santimetrelik doku örneklerinde, belirlenen miRNA ve tahmini hedef genlerinin kontrol ve stres grubuyla karşılaştırmalı olarak gen ekspresyon profilleri belirlenmiştir. Yapılan analizler sonucunda, miR528'in ekspresyonunun, kontrol şartlarında büyüme bölgeleri arasında istatistiksel olarak önemli bir fark göstermediği görülmüştür. Stres şartlarında ise, miR528'in ekspresyonunun sadece meristem bölgesinde istatistiksel olarak önemli bir artış gösterdiği 
saptanmıştır $(\mathrm{P}<0.05)$ (Şekil 3.1). miR528'in tahmini hedef geni olan SOD 1-a gen ekspresyon profiline bakıldığında, kontrol ve stres koşullarında meristem bölgesinden uzama ve olgunluk bölgelerine doğru gidildikçe artan bir profil sergilediği görülmüştür. Ancak, üşüme stresi, her üç büyüme bölgesinde de SOD 1-a ekspresyonunda kontrole göre bir farka yol açmamıştır $(P>0,05)$. miR528'in tahmini hedef geni SOD 1-a transkriptini hedef almasi sonucunda, aralarında antagonist bir ilişki olması beklenmektedir.
$\mathrm{Bu}$ bağlamda, elde edilen veriler, stres koşullarında miR528'in meristem bölgesinde önemli derecede artış gösterdiği ve tahmini hedefi olan SOD 1-a genini burada baskılamış olabileceğini düşündürmektedir. $\mathrm{Bu}$ bulgular, miR528'in SOD1-a genini hedef alarak ekspresyonunu negatif yönde düzenlediğini ve böylece hücre uzaması ve farklılaşması faaliyetlerini etkilemeksizin, hücre bölünmesi işlevlerinde dolaylı rol alabileceğine işaret etmektedir.
A

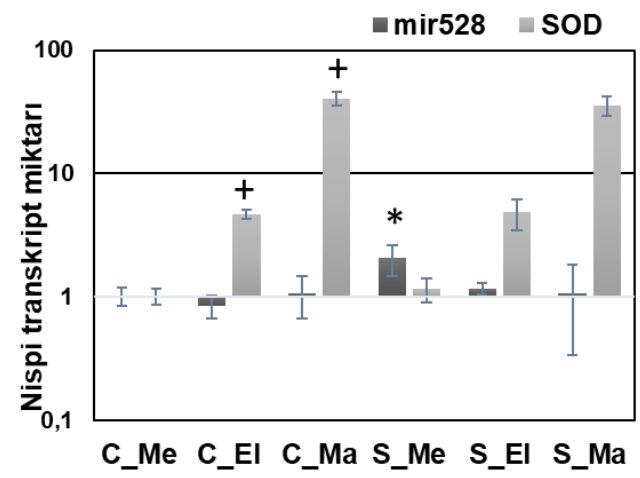

B

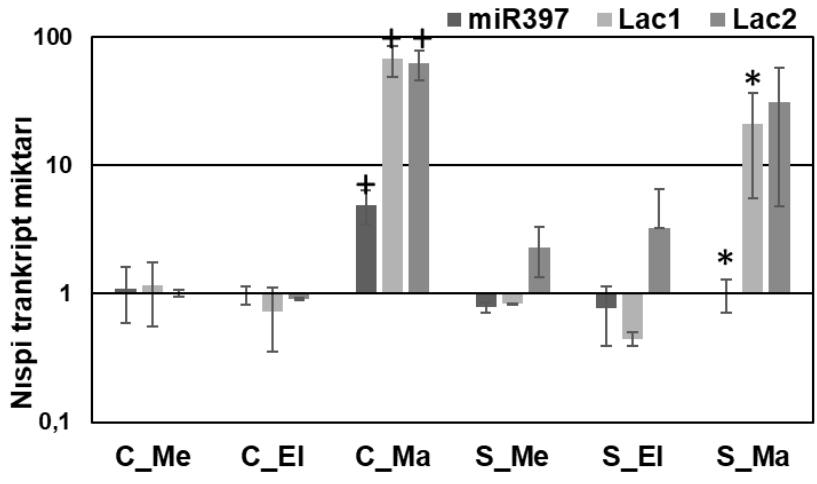

Şekil 3.1. A) ADA313'ün dördüncü yaprağının büyüme bölgelerinde miR528 ve tahmini hedefi Süperoksid 1a (SOD)'un, B) ADA313'ün dördüncü yaprağının büyüme bölgelerinde miR397 ve tahmini hedefleri Lakkaz 1 (Lac1) ve Lakkaz 2 (Lac2)'nin kontrol (C) ve üşüme stresi (S) şartlarındaki ifade profilleri. Y ekseni logaritmik ölçeklidir. $\mathrm{Me}=$ meristem, $\mathrm{El}=$ uzama, $\mathrm{Ma}=$ olgunluk, (+ büyüme bölgeleri arasında farkl1, *stres ve kontrol şartları arasında farkl1, $\mathrm{n}=3$; ort $\pm \mathrm{ss}, \mathrm{P}<0,05)$.

Arabidopsis bitkisinde, Cu-Süperoksit dismutaz-1 (CSD1) ve Cu-Süperoksit dizmutaz-2 (CSD2) genlerinin soğuk muamelesi sonucu meydana gelen oksidatif stres sırasında, miR408 ile regüle edildiği bildirilmiştir (Ma ve ark., 2015). Bu ve benzeri çalışmalar, miRNA'ların farklı bitkilerde farklı genleri hedefleyebildiği gibi aynı genler farklı miRNA'lar tarafindan da hedeflenebileceğini göstermiştir (Wei ve ark., 2009). Ayrica, miRNA ve hedef genleri arasinda her zaman antagonist ilişkinin olmadığ 1 ve bu durumun strese veya gelişimsel süreçlere bağlı olarak değişebildiği de ifade edilmektedir.

Yapılan in-siliko analizler sonucunda redoks regülasyonunda muhtemel rol oynadığ miR397 geninin, tahmin edilen Lakkaz 1 (Lac1) ve Lakkaz 2 (Lac2) genlerini hedef alması koşulunda, aralarında antagonist bir ilişkinin olması beklenmektedir. $\mathrm{Bu}$ bağlamda, yapılan qRT-PCR analizleri sonucunda miR397 ekspresyonunun, kontrol şartlarında, olgunluk bölgesinde, meristem ve uzama bölgelerine oranla istatistiksel olarak önemli derecede arttığ1 saptanmıştır $\quad(\mathrm{P}<0.05) \quad$ (Şekil 3.1). Stres koşullarında ise, miR397 ekspresyonunda, büyüme bölgeleri arasında istatistiksel olarak önemli bir fark görülmezken, olgunluk bölgesinde miR397 ekspresyonunun üşüme stresine cevap sirasinda istatistiksel olarak önemli derecede azaldığı saptanmıştır $(\mathrm{P}<0,05)$. Benzer şekilde, tüm buğday fidesinin kullanılarak yapılan bir çalışmada, soğuk stresinde miR397'nin ekspresyonunun azaldığg gösterilmiştir (Gupta ve ark., 2014). Lac1 ve Lac2 ekspresyonlarının ise, olgunluk bölgesinde, meristem ve uzama bölgesine göre istatistiksel olarak önemli derecede arttığı ve ayrıca Lac1 ekspresyonunun stres sırasında azaldığı tespit edilmiştir $(\mathrm{P}<0.05)$. Buna karşın, Arabidopsis'de Lac3 geninin oksidatif stres sırasında arttığını gösterilmiştir (Ma ve ark., 2015). Ancak, miR397 ve in silico analizler ile belirlenen tahmini hedefleri Lac1 ve Lac2 genleri arasında, büyüme bölgeleri ve stres koşullarında qRTPCR ile antagonist ekspresyon profilinin tespit edilememesi aralarındaki ilişkinin farklı deneysel tekniklerle doğrulanmasını gerektirmektedir.

\subsection{Enzimatik ve Biyokimyasal Analizler}

ADA313 hibrid mısırının üşüme stresine tolerans1 sırasında yaprak büyüme işlevlerinin olası miRNA aracılıklı redoks regülasyonundan nasıl etkilendiğini enzimatik ve biyokimyasal seviyede belirlemek için, başlica oksidatif enzimlerin aktivite deneyleri, $\mathrm{H}_{2} \mathrm{O}_{2}$ ve ROS hasarını gösteren manoldialdehid (MDA) miktarı tayin analizleri yapılmıştır. Bu bağlamda, kontrol ve stres koşullarında yetiştirilen fidelerin dördüncü yaprakları, büyümenin sabit fazında hasat edilerek, tüm büyüme bölgelerini içeren yaprak tabanından itibaren yaklaşık on cm'lik kısım, bir cm'lik parçalara ayrılarak 
analiz edilmiştir. Ancak, in silico analizler ve literatür çalışmalarıyla sadede SOD 1a geninin miR528 tarafindan hedeflendiği tahmin edilebilmiştir. Süperoksid dismutaz (SOD) enzim aktivitesinin, kontrol şartlarında büyüme bölgeleri arasında fark göstermezken, stres koşullarında, uzama bölgesinde istatistiksel olarak önemli derecede azaldığı saptanmıştır $(\mathrm{P}<0.05)$ (Şekil 3.2). Benzer şekilde, Avramova ve ark. (2015), mısır bitkisinde, kuraklık stresine karşı yaprak büyüme cevabında SOD enzim aktivitesinin en yüksek meristem bölgesinde olduğu gözlenmiştir. Buna ek olarak, bu çalışmada, SOD enzim aktivitesinin meristem ve olgunluk bölgelerinde en yüksek olması, stres toleransı sirasında hücre bölünmesi başta olmak üzere hücresel homeostazisin sağlanmasındaki rolüne işaret etmektedir. SOD 1a geninin ekspresyonunda ise meristemden uzama ve olgunluk bölgelerine doğru önemli derecede artış gözlenirken, stres şartlarında önemli bir fark saptanmamışıı (Şekil 3.1). SOD enzim aktivitesi ve gen ekspresyonunda gözlenen bu farklılı̆̆ın, bitkide farklı SOD izoenzimlerin varlığından kaynaklandığı düşünülmektedir. Yine, Wang ve ark. (2016)'nın yaptıkları çalışmada, üşüme stresi şartlarında yetiştirilen mısır bitkisinin yapraklarında SOD enzim aktivitesinin arttı̆̆ını göstermişlerdir.

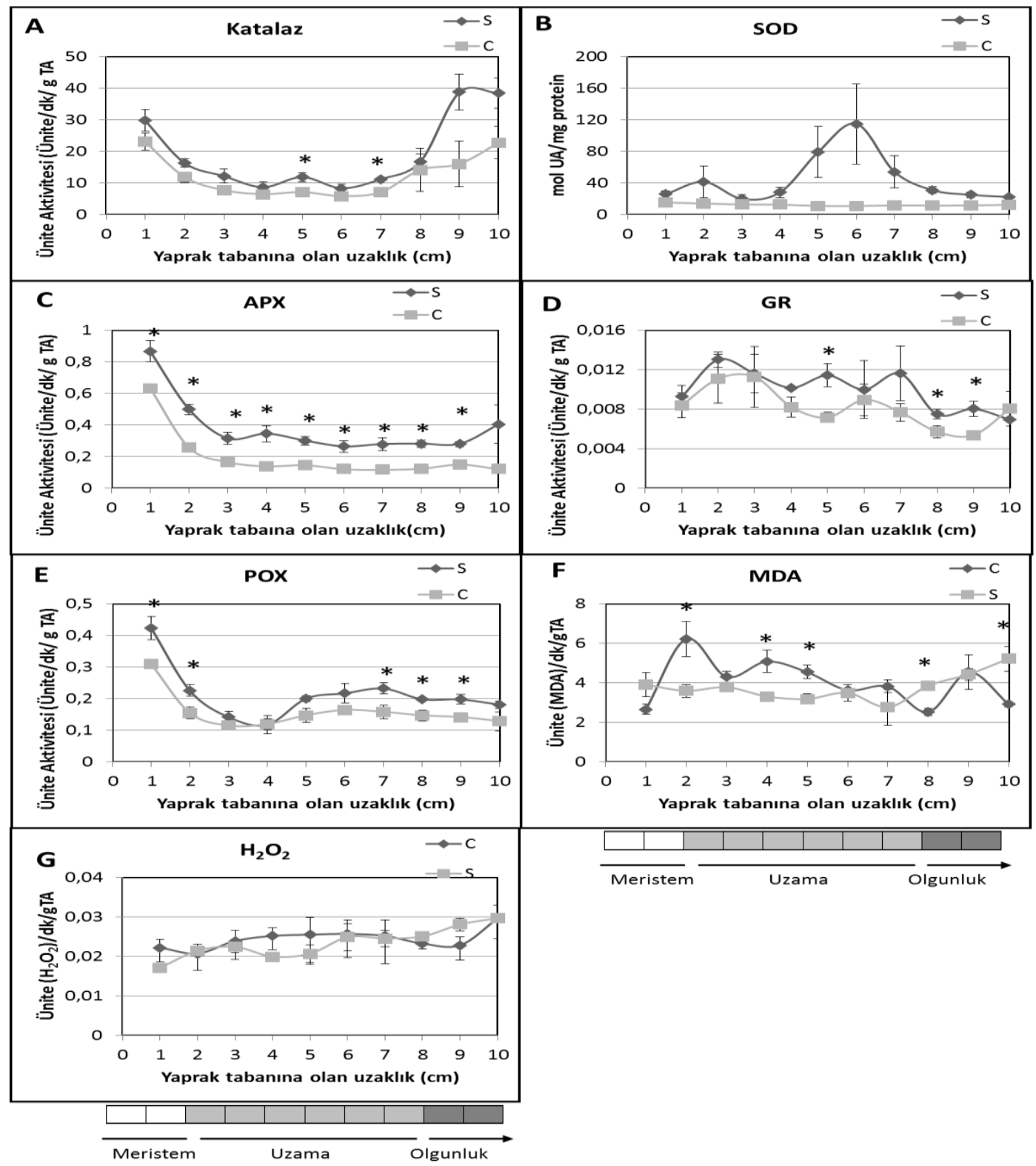

Şekil 3.2. Temel antioksidan enzimlerin üşüme stresi sırasında ADA313 misır hibridinin dördüncü yaprağının büyüme bölgeleri (meristem $(1-2 \mathrm{~cm})$, uzama $(2-8 \mathrm{~cm})$ ve olgunluk $(8-10 \mathrm{~cm}))$ arasındaki aktiviteleri. A) Katalaz aktivitesi, B) Süperoksid dizmutaz (SOD) aktivitesi, C) Askorbat peroksidaz (APX) aktivitesi, D) Glutatyon redüktaz (GR) aktivitesi, E) Peroksidaz (POX) aktivitesi, F) Manoldialdehit (MDA) miktarı, G) $\left(\mathrm{H}_{2} \mathrm{O}_{2}\right)$ miktarı. *kontrol ve üşüme stresi şartlarındaki fark, $\mathrm{n}=3$, ort $\pm \mathrm{ss}, \mathrm{P}<0.05$. $\mathrm{C}=$ kontrol, $\mathrm{S}=$ üşüme stresi 
Katalaz enzim aktivitesi analiz sonuçlarına göre, katalaz aktivitesinin her iki büyütme koşulunda, meristem bölgesinden uzama bölgesine doğru azalan ve uzama bölgesinden olgunluk bölgesine geçerken tekrardan artan bir profil sergilediği görülmüştür (Çizelge 3.2). Bu bulgular, Avramova ve ark. (2015)'nın misır fidelerinin kuraklık stresi tolerans1 sırasında gözledikleri katalaz aktivitesi profili ile benzerdir. Ayrıca, katalaz enzim aktivitesinin uzama bölgesinde stres koşullarında istatistiksel olarak artması, stres toleransı sırasında hücre genişlemesi işlevindeki rolüne işaret etmektedir $(\mathrm{P}<0,05)$.

Askorbat peroksidaz (APX) enzim aktivitesinin büyüme bölgeleri arasındaki genel profiline bakıldığında, meristem bölgesinde en yüksek düzeyde olup, uzama ve olgunluk bölgelerine doğru gidildikçe azaldığı gözlenmiştir (Çizelge 3.2). Bununla birlikte, tüm büyüme bölgelerinde APX aktivitesinin, stres koşullarında istatistiksel olarak önemli derecede arttı̆g 1 saptanmıştır $(\mathrm{P}<0,05)$. Benzer şekilde, Lee ve Lee (2000)'1, salatalık yaprakları üzerinde yaptığı çalışmada, üşüme stresinin APX aktivitesi arttırdığını saptamışlardır.

Peroksidaz (POX) enzim aktivitesinin ise, meristem bölgesinde en yüksek ve uzama ve olgunluk bölgelerine doğru gidildikçe azalan bir profil gösterdiği saptanmıştır (Çizelge 3.2). Ayrıca, POX aktivitesinin stres koşullarında meristem ve olgunluk bölgelerinde istatistiksel olarak önemli derecede $\operatorname{arttığ~} 1$ tespit edilmiştir $(\mathrm{P}<0.05)$. Benzer şekilde, Avramova ve ark. (2015)'nin yaptıkları çalışmada, mısır fidelerinde kuraklık stresi sonucu POX aktivitesinin en yüksek meristem bölgesinde olduğunu gözlemișlerdir. Bununla birlikte, olgunluk bölgesinde POX aktivitesinin üşüme stresine cevapta artmış olası ile kuraklık stresi cevabından farklılık arz etmektedir. POX'un, meristem bölgesinde aktif olarak hücre bölünme işlevlerini tetikleyerek büyümeyi düzenlediği literatürdeki çalışmalarda bildirilmiştir (Crevecoeur ve ark., 1997; Tsukagoshi ve ark., 2016).

Glutatyon redüktaz (GR) enzim aktivitesinin, stres koşullarında yetiștirilen misır fidelerinde, kontrol şartlarında yetiştirilen mısır fidelerine göre, uzama ve olgunluk bölgelerinde istatistiksel olarak önemli arttı̆̆ 1 görülmüştür $(\mathrm{P}<0,05)$ (Çizelge 3.2). Benzer şekilde, Hola ve ark. (2007)'nın üşüme stresine dirençli ve hassas mısır çeşitleri üzerinde yaptıkları çalışmada, üşüme stresi sırasında GR enzim aktivitesinin üşümeye dirençli ve hassas mısır yapraklarında artığı saptanmıştır.

Hidrojen peroksit $\left(\mathrm{H}_{2} \mathrm{O}_{2}\right)$ miktarının, stres koşullarında meristem ve olgunluk evrelerinde yüksek uzama bölgesinde düşük seviyede olduğu tespit edilmiştir. Benzer şekilde, mısır bitkisinin kuraklık stresi toleransı sırasında yapılan bir diğer çalışmada, $\mathrm{H}_{2} \mathrm{O}_{2}$ miktarının meristemden uzama bölgesine doğru azalan, uzama bölgesinden olgunluk bölgesine geçerken tekrardan artan bir profil sergilemiştir (Avramova ve ark., 2015) (Şekil 3.2).

Oksidatif stres sırasında ROS'ların lipid peroksidasyonu sonucu olarak ortaya çıkan manoldialdehit (MDA)'in miktarı, ilginç bir şekilde, kontrol şartlarında yetiştirilen fidelerin yapraklarının meristem ve uzama bölgelerinde, olgunluk bölgesine ve stres koşullarına göre daha fazla olduğu tespit edilmiştir $(\mathrm{P}<0,05)$ (Çizelge 3.2). Burada, hücre bölünmesi ve hücre genişlemesi işlevleri sırasında membran lipidlerinin peroksidayonunun meydana geldiğ görülmektedir. Ancak, stres koşullarında MDA miktarında meristem ve uzama bölgesinde meydana gelen azalış, üşüme stresinin hücre zarı akışkanlığını azaltması sonucu hücre bölünmelerini sekteye uğratmasına bağlı olabilir. Stres koşullarında ise, MDA miktarında olgunluk bölgesinde artış saptanmıştır $(\mathrm{P}<0,05)$. Bu bulgu, üşüme stresi sırasında ortaya çıkan ROS'lardan kaynaklandı̆̆ına işaret etmektedir. Avramova ve ark. (2015), misır fidelerinde kuraklık stresi etkisiyle, MDA miktarında meristem ve uzama bölgeleri arasında fark rastlanmazken, olgunluk bölgesinde artış gözlemişlerdir. Burada, özellikle soğuk stresinin diğer streslerden farklı olarak lipid akışkanlığını etkileyerek membran faaliyetlerini doğrudan etkilediği açıkça görülmektedir.

\section{Sonuç}

Üşüme stresine maruz kalan misır fidelerinde, dördüncü yapraklarının uzunluğunda $\% 26$, yaprak uzama oranında ise \% 19 azalma olduğu görülmüştür. Ancak kontrol ve stres şartlarında yetiştirilen mısır fidelerinin klorofil miktarları arasında istatistiksel olarak önemli bir fark olmadığı saptanmıştır. miR528'in stres koşullarında meristem bölgesine spesifik olarak ifade olduğu gözlenmiştir. Ancak, miR528 ve tahmini hedefi olan SOD arasında resiprokal (karşılıklı çapraz) ifade profili gözlenmediğinden aralarındaki ilişskinin daha ileri analizlerle doğrulanması gerekir. miR397 ve tahmini hedefleri olan Lac1 ve Lac2'nin olgunluk bölgesine spesifik olduğu gözlenirken strese bağl1 olarak ifadelerinin azaldığı saptanmıştır. Sonuç olarak, miR528 ve miR397'nin genetik mdifikasyonları, strese toleranslı çeşit geliştirme programları için önerilmektedir.

Katalaz enzim aktivitesinin meristemden uzama bölgesine doğru azalan, uzama bölgesinden olgunluk bölgesine doğru artan bir profil sergilemiştir. SOD enzim aktivitesinin stres koşullarında uzama bölgesinde istatistiksel olarak önemli derecede azaldığ saptanmıştır. Ancak, SOD gen ifadesinde benzer profile rastlanmaması gözlenen sonucun farklı SOD izoenzimlerinin varlığına bağlı olabileceğini göstermektedir. APX enzim aktivitesinin, meristem bölgesinde artan, uzama ve olgunluk bölgelerine doğru gidildikçe azalan bir profil göstermesi, meristem faaliyetlerindeki olası rolüne işaret etmektedir. Ayrıca, APX aktivitesi tüm büyüme bölgelerinde strese bağlı 
olarak artış göstermiştir. GR enzim aktivitesinin stres koşullarında yetiştirilen misır fidelerinde, kontrol şartlarında yetiştirilen mısır fidelerine göre dördüncü yaprak segmentinden itibaren istatistiksel olarak önemli derecede arttığı gözlenmiştir. POX enzim aktivitesi ise, meristem bölgesinden uzama bölgesine doğru gittikçe azalan bir profil sergilemiştir ve bundan dolayı meristem faaliyetlerinde düzenleyici role sahip olduğu tahmin edilmektedir. Sonuç olarak, biyoinformatik araçların da hızla gelişmekte olmasına paralel olarak, yeni miRNA ve hedef antioksidan geni tanımlanmasina olanak doğacaktır. $\mathrm{Bu}$ bağlamda, miRNA modifikasyonu ile hücrenin redoks durumu regülasyonu sağlanarak antioksidan enzimlerin aktiviteleri yeniden düzenlemek suretiyle bitkide stres toleransinın artırılması mümkün olacaktır.

\section{Teşekkür}

Bu proje TÜBİTAK tarafından $115 Z 527$ nolu ve GTÜBAP-2017-A-105-42 nolu projeler tarafindan desteklenmiştir.

\section{Kaynaklar}

Aebi, H.E., 1983. Catalase. In: Bergmeyer, H.U., Ed., Methods of Enzymatic Analysis, Verlag Chemie, Weinhem, 273- 286.

Avramova, V., AbdElgawad H., Zhang, Z., Fotschki, B., Casadevall, R., Vergauwen L., Knapen, D., Taleisnik, E., Guisez, Y., Asard, H., Beemster, G.T., 2015. Drought induces distinct growth response, protection, and recovery mechanisms in the maize leaf growth zone. Plant Physiology, 169, 13821396.

Banowetza, G.M., Dierksena, K.P., Azevedoa, M.D., Stout, R., 2004. 'Microplate quantification of plant leaf superoxide dismutases. Analytical Biochemistry, 332, 314-320.

Bartel, D.P., 2004. MicroRNAs: genomics, biogenesis, mechanism, and function. Cell, 116, 281-297.

Beemster, G.T.S., Fiorani, F., Inze, D., 2003. Cell cycle: The key to plant growth control?. Trends in Plant Science, 8, 154-158.

Boudolf, V., Vlieghe, K., Beemster, G.T., Magyar, Z., Torres-Acosta, J.A., Maes, S., Van Der Schueren, E., Inze, D., De Veylder, L., 2004. The plantspecific cyclin-dependent kinase CDKB1;1 and transcription factor E2Fa-DPa control the balance of mitotically dividing and endoreduplicating cells in Arabidopsis. The Plant Cell, 16, 2683-2692.

Bradford, M.M., 1976. A rapid and sensitive method for the quantitation of microgram quantities of protein utilizing the principle of protein-dye binding. Analyt. Biochem. 72, 248-254.

Carlberg, I. N. C. E. R., \& Mannervik, B. E. N. G. T. (1975). Purification and characterization of the flavoenzyme glutathione reductase from rat liver. Journal of biological chemistry,250(14), 5475-5480.

Crevecoeur, M., Marcela, P., Greppin, H., Penell, C., 1997. Peroxidase activity in shoot apical meristem from Spinaci. Acta Histochemica, 99, 177-186.

Chavez-Hernandez, E.C., Alejandri-Ramirez, N.D., Juarez-Gonzalez V. T., Dinkova, T. D., 2015. Maize miRNA and target regulation in response to hormone depletion and light exposure during somatic embryogenesis. Frontial Plant Science, 22;6: 555-569.

Chance, B., Maehly, A.C., 1995. Assay of catalases and peroxidases. Methods in Enzymology, 2, 764-775.

Chen, C., Ridzon, D.A., Broomer, A.J., Zhou, Z., Lee, D.H., Nguyen, J.T., Barbisin, M., Xu, N.L., Mahuvakar, V. R., Andersen, M.R., Lao, K.Q., Livak, K.J., Guegler, K.J., 2005. Real-time quantification of microRNAs by stem-loop RTPCR. Nucleic Acids Research, 33 (20), e179.

Choudhury, F.K., Rivero, R.M., Blumwald, E., Mittler, R., 2017. Reactive oxygen species, abiotic stress and stress combination. The Plant Journal, 90, 856-867.

Chinnusamy, V., Zhu, J., Zhu, J., 2007. Cold stress regulation of gene expression in plants. TRENDS in Plant Science, 12, 10.

Considine, M.J., Foyer, C.H., 2014. Redox regulation of plant development. Antioxid Redox Signal. 20;21(9):1305-26.

Dai, X., Zhuang, Z., Zhao, P.X., 2018. psRNATarget: a plant small RNA target analysis server (2017 release). Nucleic Acids Res. 46, W49-W54.

De Azevedo Neto, A.D., Prisco, J. T., Enéas-Filho J., de Abreu, C.E.B., Gomes-Filho, E., 2006. Effect of salt stress on antioxidative enzymes and lipid peroxidation in leaves and roots of salt-tolerant and salt-sensitive maize genotypes. Environmental and Experimental Botany, 56, 87-94.

Eker, S., Ozturk, L., Yazici, A., Erenoglu, B., Romheld, V., Cakmak, I., 2006. Foliar-applied glyphosate substantially reduced uptake and transport of iron and manganese in sunflower (Helianthus annuus L.) plants. J Agric Food Chem. Dec 27;54(26):1001925.

Gupta, O.P., Meena, N.L., Sharma, I., Sharma P., 2014. Differential regulation of microRNAs in response to osmotic, salt and cold stresses in wheat. Molecular Biology Reports, 41,4623-4629.

Heath, R. L., \& Packer, L. 1968. Photoperoxidation in isolated chloroplasts: I. Kinetics and stoichiometry of fatty acid peroxidation. Archives of biochemistry and biophysics, 125(1), 189-198.Inze, D., Veylder, L., 2006. Cell Cycle Regulation in Plant Development. The Annual Review of Genetics, 40, 77-105.

Jones-Rhoades, M.W., Bartel, D.P., 2004. Computational identification of plant microRNAs and their targets, including a stress-induced miRNA. Moleculer Cell, 14, 787-799. 
Kayıhan, D.S., Kayıhan, C., Çiftçi, Y.Ö., 2016. Excess boron responsive regulations of antioxidative mechanism at physio-biochemical and molecular levels in Arabidopsis thaliana. Plant Physiology and Biochemistry, 109:337-345.

Khraiwesh, B., Zhu, J.K., Zhu, J., 2012. Role of miRNAs and siRNAs in biotic and abiotic stress responses of plants. Biochim Biophys Acta., 1819(2):137-48.

Kumar, A., Sharmaa, K.K., Kumar, P., Ramchiaryb, N., 2015. Laccase isozymes from Ganoderma lucidum MDU-7: isolation, characterization, catalytic properties and differential role during oxidative stress. Journal of Molecular Catalysis B: Enzymatic $113,68-75$.

Lee, D.H., Lee, C.B., 2000. Chilling stress-induced changes of antioxidant enzymes in the leaves of cucumber: in gel enzyme activity assays. Plant Sci., 16;159(1):75-85.

Lee, S.J., Jeong, E.M., Ki, A.Y., Oh, K.S., Kwon, J., Jeong, J.H., Chung, N.J., 2016. Oxidative defense metabolites induced by salinity stress in roots of Salicornia herbacea. J Plant Physiol., 1(206): 133142.

Li, L., Yi, H., Xue, M., Yi, M., 2017. miR398 and miR395 are involved in response to $\mathrm{SO}_{2}$ stress in Arabidopsis thaliana. Ecotoxicology. 26(9):11811187.

Lichtenthaler, H.K., Buschmann, C., 2001. Current Protocols in Food Analytical Chemistry, F4.3.1F4.3.8.

Liu Q, Hu H, Zhu L, Li R, Feng Y, Zhang L, Yang Y, Liu X, Zhang H. 2015. Involvement of miR528 in the regulation of arsenite tolerance

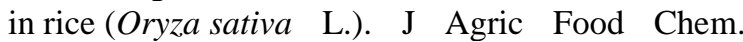
14;63(40): 8849-8861. Ma, C., Burd, S., Lers, A. 2015. miR408 is involved in abiotic stress responses in Arabidopsis. The Plant Journal, 84: 169-187.

Mabuchi, K., Maki, H., Itaya, T., Suzuki, T., Nomoto, M., Sakaoka, S., Morikami, A., Higashiyama, T., Tada, Y., Busch, W., Tsukagoshi, H., 2018. MYB30 links ROS signaling, root cell elongation, and plant immune responses. Proc Natl Acad Sci U S A. 15;115(20): E4710-E4719.

Menon, S.G., Goswami, P.C., 2007. A redox cycle within the cell cycle: ring in the old with the new. Oncogene. 22;26(8): 1101-1109.

Nakano, Y., Asada, K., 1981. Hydrogen peroxide is scavenged by ascorbatespecific peoxidase in spinach chloroplasts. Plant Cell Physiol., 22: 867-880

Palatnik, J.F., Allen, E., Wu, X., Schommer, C., Schwab, R., Carrington, J.C., Weigel, D. 2003. Control of leaf morphogenesis by microRNAs. Nature, 425: 257-263.

Pfaffl, M.W., 2001. A new mathematical model for relative quantification in real-time RT-PCR. Nucleic Acids Research, 29(9): e45.

Quesada, M. A., Sfinchez-Roldfin, C., Heredia, A., Valpuesta, V., Bukovac, M.J., 1992. Peroxidase and
IAA oxidase activities and peroxidase isoenzymes in the pericarp of seeded and seedless "Redhaven" peach fruit. Journal of Plant Growth Regulation, 11: $1-6$.

Rymen, B., Fiorani, F., Kartal, F., Vandepoele, K., Inze, D., Beemster, G. T. S., 2007. Cold nights impair leaf growth and cell cycle progression in maize through transcriptional changes of cell cycle genes. Plant Physiology, 143 (3), 1429-1438.

Scandalios, J.G., 2005. Oxidative stress: molecular perception and transduction of signals triggering antioxidant gene defenses. Brazilian Journal of Medical and Biological Research, 38: 995-1014.

Sergiev, I., Alexieva, V., \& Karanov, E. 1997. Effect of spermine, atrazine and combination between them on some endogenous protective systems and stress markers in plants. Compt Rend Acad Bulg Sci, 51(3), 121-124.

Song, Q.X., Liu, Y.F., Hu, X.Y., Zhang, W.K., Ma, B., Chen, S.Y., Zhang, J.S., 2011. Identification of miRNAs and their target genes in developing soybean seeds by deep sequencing. BMC Plant Biology, 11, 5, doi: 10.1186/1471-2229-11-5.

Sun, G., 2011. MicroRNAs and their diverse functions in plants. Plant Molecular Biology, 18: 17-36.

Sunkar, R., Kapoor, A., Zhu, J., 2006. Posttranscriptional induction of two $\mathrm{Cu} / \mathrm{Zn}$ superoxide dismutase genes in Arabidopsis is mediated by downregulation of miR398 and important for oxidative stress tolerance. The Plant Cell, 18, 2051-2065.

Sunkar, R., Chinnusamy, V., Zhu, J., Zhu, J. K. 2007. Small RNAs as big players in plant abiotic stress responses and nutrient deprivation. Trends Plant Science, 12: 301-309.

Sunkar, R., Li, Y., Jagadeeswaran, G., 2012. Functions of microRNAs in plant stress Responses. Trends in Plant Science, 17(4): 196-203.

Tsukagoshi, H., 2016. Control of root growth and development by reactive oxygen species. Curr Opin Plant Biol., 29: 57-63.

Tollenaar, M., Lee, E.A. 2002. Yield potential, yield stability and stress tolerance in maize. Field Crops Research, 75: 161-169.

Varkonyi-Gasic, E., Wu, R., Wood, M., Walton, E.F., Hellens, R.P., 2007. Protocol: a highly sensitive RTPCR method for detection and quantification of microRNAs. Plant Methods, 3: 12, doi:10.1186/1746-4811-3-12.

Wang, W., Xia, M.X., Chen, J., Yuan, R., Deng, F.N., Shen, F.F., 2016. Gene expression characteristics and regulation mechanisms of superoxide dismutase and its physiological roles in plants under stress. Biochemistry (Mosc), 81(5): 465-80.

Wang, W., Vinocur, B., Altman, A., 2003. Plant responses to drought, salinity and extreme temperatures: towards genetic engineering for stress tolerance. Planta, 218: 1-14. 
Zhang, YC, Yu, Y., Wang, C.Y., Li, Z.Y., Liu, Q., Xu, J., Liao, J.Y., Wang, X.J., Qu, L.H., Chen, F., Xin, P., Yan, C., Chu, J., Li, H.Q., Chen, Y.Q., 2013. Overexpression of microRNA OsmiR397 improves rice yield by increasing grain size and promoting panicle branching. Nat Biotechnol., 31(9): 848-52.

Jagadeeswaran, G., Saini, A., Sunkar, R., 2009. Biotic and abiotic stress down-regulate miR398 expression in Arabidopsis. Planta., 229(4): 1009-14.

Xie, F.L., Huang, S.Q., Guo, K., Xiang, A.L., Zhu, Y.Y., Nie, L., Yang, Z.M., 2007. Computational identification of novel microRNAs and targets in Brassica napus. FEBS Lett., 3;581(7): 1464-1474.

Hola, D., Kocova, M., Rothova, O., Wilhelmova., N., Benesova, M., 2007. Recovery of maize (Zea mays L.) inbreds and hybrids from chilling stress of various duration: photosynthesis and antioxidant enzymes. J Plant Physiol., 164(7): 868-77.

Weii L., Zhang, D., Xiang, F., Zhang, Z., 2009. Diferentially expressed miRNAs potentially involved in the regulation of defence mechanism to drought stress in maize seedlings. International Journal of Plant Sciences, 170(8): 979-989. 